\title{
Suffering and the making of politics: Perspectives from Jaspers and Camus
}

\author{
Giunia Gatta \\ Department of Policy Analysis and Public Management, Bocconi University, 20136 Milan, Italy. \\ giunia.gatta@unibocconi.it
}

\begin{abstract}
Bonnie Honig has recently criticized the attempt to graft ethical and political principles onto the alleged universality of suffering. She considers this trend inhospitable to vigorous, democratic citizenship, and she pits a 'lamentational politics' centered on suffering and mortality against a political, agonistic humanism that focuses on life, action and courage. In this article, I inquire into how political action in concert can (and does) arise out of suffering. I characterize suffering, following Karl Jaspers, as a situation that defines being human. Yet, drawing on Jaspers and Camus, I resist its portrayal as immediately universal and anti-political. First, I transpose suffering from the plane of singular, idiosyncratic experience to that of complex situation. Second, by way of my reading of The Plague, I suggest that suffering can be privileged ground for the reconfiguration of political landscapes through its unmaking of identities in both a literal and metaphoric sense. Suffering ought not to be displaced from debates in political theory. Rather, it should become an agonistic ground of contention. It should be re-politicized. Contemporary Political Theory (2015) 14, 335-354. doi:10.1057/cpt.2014.52; published online 18 November 2014
\end{abstract}

Keywords: suffering; Jaspers; Camus; Honig; Arendt; situation

Suffering has come back as a subject of interest for political theorists. It had faded from focus as the discipline engaged in debates around Rawls's philosophy of justice in the 1970s and 1980s, but then returned to fill a foundational void in the wake of crumbling ideologies in the 1990s. The cataclysmic events of 2001 and the years following, when suffering suddenly imposed its presence on previously tranquil shores, only reinforced such a trend. In the last few decades, there has been a focus on the vulnerability of all humans to suffering and cruelty as a core on which to build a catholic set of values and a possible new foundation for political action. Theorists with very different ontological, epistemological and political commitments have engaged in this effort. Judith Shklar $(1982,1984,1989)$ appropriated the idea of 'putting cruelty first' for her liberalism of fear. In the wake of Shklar, Richard Rorty

(C) 2015 Macmillan Publishers Ltd. 1470-8914 Contemporary Political Theory Vol. 14, 4, 335-354 www.palgrave-journals.com/cpt/ 
put the avoidance of cruelty as the cornerstone of his proposal for liberal ironism, a preference 'ungroundable' in foundations but retaining, in his eyes, moral and political traction (1989). Stephen White emphasized finitude and mortality as the weak ground to sustain what he calls a 'late-modern ethos' (2009). Judith Butler's reflections in the aftermath of $9 / 11$ also pointed towards being vulnerable as constitutive of being human, and as a possible source of solidarity (2006).

Bonnie Honig has in recent work criticized this trend as inhospitable to vigorous, democratic citizenship, and has pitted a 'lamentational politics' centered on suffering and mortality against a political, agonistic humanism that focuses on life, action and courage (2013). Against the universalism of suffering and mourning, Honig reads Antigone's lamentation as an intrinsically and deliberately political act. In the first part of Antigone, Interrupted she suggests that a focus on finitude and grievability makes for lame politics, and in the second she builds her case for lamentation as a political vernacular: 'plural, various, contested, partisan' (2013, p. 89). But in Honig's hands Antigone's suffering all but disappears amidst plots, strategies and the relentless attempt to take Creon down.

In this article, I want to pursue an understanding of suffering that resists being cast as foundational, universal and anti-political, without ceasing to be a focus of inquiry. Drawing on Karl Jaspers and Albert Camus, I want to make the case for suffering as a situation, as in itself plural, contested and political. I aim at disrupting the binary proposed by Honig between lamentational politics and agonistic humanism in two ways. First, I want to show how suffering itself can be read through agonistic rather than moralizing lenses, by transposing it from the plane of singular experience to that of complex situation. Second, I want to suggest that suffering sometimes constitutes privileged ground for the reconfiguration of political landscapes by unmaking identities in both a literal and metaphoric sense, in a very unique way.

Honig seems to suggest, in the wake of Hannah Arendt (1963), that solidarity and natality should be the political categories of interest, while suffering constitutes mere passivity and ushers in an antipolitical humanism. Honig repeatedly articulates her qualms with a politics of lamentation by italicizing the second term. She wants to recover a politics of lamentation instead. Yet, when she moves to discuss the latter, there is little lamentation (and hardly any suffering) left, and her arguments seem to draw back to her support for agonism regardless of the background of suffering. There seems to be no distinctiveness to politics in the wake of suffering. This latter theme is what I want to explore. One way to put it is that Honig in Antigone, Interrupted undertakes the project of agonizing suffering; my own project is agonizing suffering. I dwell on suffering, on its literal unmaking of bodies - individual and politic - as a crucial force in politics, rather than as a coolly considered excuse to plot and conspire.

Hannah Arendt and many of those inspired by her, including Honig, address the question of suffering by demoting it from the realm of public concerns. Suffering has often a material character to it: it has to do with needs that have to be fulfilled. Those needs contaminate the symmetrical and reciprocal relationships that are, for Arendt, distinctive of the public realm. Immediate needs bring to the forth, beside themselves, 
something else that ought not to appear in the public realm: asymmetrical relationships, deep inequality and the ability to coerce that this inequality invites. The kind of unmaking that suffering enacts is unfit for public appearance because it undermines individual agency and freedom: it reduces us to silence (or inarticulate screams) and passivity, which are the opposite of speech and action, what properly appears in the public realm (the classic reference here is Arendt, 1963). Yet, by closing politics off from the more visceral kind of unmaking that suffering threatens, Arendt deprives herself of the ability to make sense of the radical kind of refiguring and rebuilding that may occur in its wake, let alone of appreciating as (potentially) political the immediate passions and emotions that arise after national trauma or, say, particularly violent civil conflict. And both Arendt and Honig, by assuming a radical alterity between suffering and political action, neglect the possible transition from one to the other. Because suffering is so central to contemporary political discourse, I do not believe it can be simply insulated and regarded as the domain of a remedial politics that is not really political, by Arendt's standards.

While one may look with favor on, and aspire to, a public realm unmarked by disabling inequalities, and instead inhabited by strong, fearless, healthy, well-fed, and well-sheltered citizens, one may still wonder how to get there from this, rather messier, side of the wall. Even if suffering were mute and inarticulate, as Arendt assumes, how can we conceive of it as not the absolute other from politics, but as already inhabiting it at its (admittedly most disempowering and disempowered) end? How do we make it speak, and importantly make it speak not with just one, but many different voices? My suggestion will be that if we attend to it as a situation, suffering already speaks with many different voices.

Contrary to the qualms Honig has with the theorists mentioned earlier, my emphasis is - with Jaspers - not on suffering as a unifying force, but as a shatterer of unity and unities, and on the peculiarly radical practices that can arise in the wake of the shattering. Suffering can unmake one's identity and facilitate awareness of the self as situated, and political communities can become unbound in the wake of national trauma. These instances may constitute moments of possibility for the redefinition of bounds, as both Judith Butler and Emma Hutchison have persuasively argued in the different contexts of the US after 9/11, and Australia after the Bali Bombing (Butler, 2006; Hutchison, 2010).

With Honig (and Arendt), I want to be sensitive to the dangers of presenting suffering as a universal, foundational or natural experience. Beyond her, I want to focus on the possibilities for suffering itself to become ground for contention, contestation, but also communication. Certainly suffering is at least partly a prepropositional force (Rorty, 1989, pp. 88 and 94), and therefore not traditionally speaking political (its pre-propositional nature is precisely what lures some into endowing it with universal character). Yet, because it is pre-propositional, it constitutes ground for signification and re-signification. That signification and re-signification is, I argue, quintessentially political. ${ }^{1}$ I want to suggest that it is 
important to attend to the potentially political dimensions that open within suffering when it is not merely experienced (individually), but understood as a defining, yet importantly mediated trait of the human condition. Conflicting interpretations and significations of suffering need not mean that each context will be insular or impenetrable, but rather that the signification itself should be interrogated, politicized and contested.

In pursuit of this difficult task I draw on the work of Karl Jaspers and Albert Camus to present suffering as a situation, rather than universal foundation or a purely individual experience, a situation within which different voices and points of view may inhabit. In his work as a psychiatrist, Jaspers points to empathy as the dynamic through which these different points of view emerge: when I empathize with another, I undergo a dialectical movement of both bracketing and drawing on my own experience. This dialectical movement creates a space, both existential and material, which at the same time unites and distances individuals. It creates a situation (Gatta, forthcoming).

In the first part of the article, I suggest that Jaspers gives us via the notions of empathy, situation, and particularly boundary situation, the instruments to account for the profound solitude suffering sometimes generates, while allowing us to apprehend it as something not purely individual, and to appreciate its potentially political (rather than universal) dimension. He takes as his starting point the situated individual, and traces an existential path from the denial of suffering, and its view as an abstract and extraneous experience, to embracing it as an inescapable and defining trait of the human condition. This embracing, together with growing awareness that suffering is in this sense (but only in this sense) universal and somehow shared, becomes key for the translation of the experience of suffering into political action. I propose Jaspers's 'desultory genesis' of boundary situations as a way of mediating between proponents of suffering as a universal experience immediately impinging on one's responsibility (I focus on Butler), and critics who fear that this move silences vigorous political exchange and too quickly covers over conflict and differences. On one hand, situation for Jaspers characterizes a fundamental aspect of the human condition (we cannot help but being situated), something that is shared. On the other hand, we are situated differently and live differently through our situations: specific times, places and interactions with others importantly mediate our suffering. Suffering is a situation in this sense: common and idiosyncratic at the same time. It is also a particular kind of situation, a 'boundary' situation, like death, guilt and struggle. These situations can become moments of existential awareness, whose relevance for politics I highlight in the article.

In the second part, I bring this phenomenology of suffering to bear on Camus's The Plague and use some of its characters to illuminate how creative political action and new public spaces can arise out of suffering. I conclude by reconnecting this phenomenological work to the claim that suffering can itself be plural, contested and political. 
One clarification about my units of analysis. Although I think that cultural clashes in the signification of suffering are of utmost political significance (for example, in cases in which international intervention is invoked to ease the suffering of certain groups in faraway countries, which may not be regarded as suffering by its 'victims'), they are not my immediate concern in the article. I draw attention here to the differences in signification at a more fundamental, individual level. ${ }^{2}$ I am looking at how (new) communities of political action may arise from this very idiosyncratic level, when an individual experience of suffering is apprehended as a broader situation of suffering.

\section{Alone, Yet Together: Suffering as (Boundary) Situation}

When for the third time the fiery wave broke on him, lifting him a little, the child curled himself up and shrank away to the edge of the bed, as if in terror of the flames advancing on him, licking his limbs ...

When the spasm had passed, utterly exhausted, tensing his thin legs and arms on which, within forty-eight hours, the flesh had wasted to the bone, the child lay flat, racked on the tumbled bed, in a grotesque parody of crucifixion ...

In the small face, rigid as a mask of grayish clay, slowly the lips parted and from them rose a long, incessant scream, hardly varying with his respiration, and filling the ward with a fierce, indignant protest, so little childish that it seemed like a collective voice issuing from all the sufferers there (Camus, 2004, pp. 189-90). ${ }^{3}$

Reading this passage is witnessing pain at its most private. This boy is helpless and alone. Nothing seems to be able to bridge the distance that suffering puts between him and everyone else. Suffering is an isolating experience, difficult to communicate and translate into words. As Elaine Scarry perceptively put it, 'to have pain is to have certainty; to hear about pain is to have doubt' (1985, p. 13). The curling up of the boy physically expresses the multiple ways in which suffering of all kinds can make us want to shrink and disappear to ourselves and to others.

Suffering can drive a wedge in the most solid and strong of relationships. In Camus's The Plague, the closing of the walls around the city of Oran to limit contagion provides a metaphor for the isolation in which those suffering are thrown. Suffering isolates us from those who are not suffering, and may force us into a common situation with others we have not chosen. The dwellers of the city of Oran are quite literally forced upon one another with no possibility of escape. An impenetrable boundary, physical, emotional and psychological, is thrown around them. The closing of the walls reconfigures relationships without any regard for personal inclinations or sympathies and constitutes an artificial community, oblivious 
to lines of pre-existing bonds and attachments. The dwellers in Oran find it impossible 'through the dead phrases, to convey some notion of their ordeal' to those outside, and see their attempts at communicating with them as futile monologues 'with a blank wall' (2004, p. 62). The sympathy that others far away try to send over the radio airwaves also crashes against the wall:

From the ends of the earth, across thousands of miles of land and sea, kindly, well-meaning speakers tried to voice their fellow-feeling, and indeed did so, but at the same time proved the utter incapacity of every man truly to share in suffering which he cannot see. $(2004$, p. 124)

Nor can a true sense of community be found within the city's walls, during those first few days of isolation: in extreme solitude 'none could count on any help from his neighbour; each had to bear the load of his troubles alone' (2004, p. 68). Suffering isolates. It severs the most profound of ties by making words inadequate, inappropriate, and dead to the task of communicating and bringing together. ${ }^{5}$ Stephen White describes 'existential realities' as 'universal constitutives of human being', whose meaning is nevertheless 'irreparably underdetermined in any categorical sense' (2000, p. 9). ${ }^{6}$ Suffering appears to be one of those realities, insofar as it is an experience that defines the human condition in general, but is also deeply idiosyncratic: the kind of universality that suffering harbors is indeed irreparably underdetermined, expressed but also concealed in a scream, its path to articulation rough and insecure.

And yet. Let us briefly return to the passage describing the agony of the suffering child, quoted above. The boy is alone in the face of terrible pain. But he also is not. His inarticulate scream hits the bystanders as a 'fierce, indignant protest', and there is something about that scream that in fact seems to encompass and unite all the sufferers there as if in a 'collective voice', suggesting the scream of pain as some sort of indication that when we suffer we cannot but turn to others and somehow outside of ourselves, transgressing our boundaries literally and metaphorically. ${ }^{7}$ There are indeed people in the room who are watching him, feeling equally helpless. If we read the whole novel, we learn that the boy's agony and his death are a turning point for many of the characters. Importantly, the boy's suffering is being described, and by this very act it attains some measure of publicity.

While suffering may be a lonely enterprise, seeing suffering, articulating suffering and giving suffering signification, often create around that loneliness a space of interpretation and responsibility that one may begin to call political. In this space, the scream of someone (the boy, in the scene above) is not only a physiological expression of pain, but also a claim to the attention, acknowledgment, and possibly the action of others. The fact that suffering can be intensely private and idiosyncratic should not blind us to the fact that its intensity often reverberates publicly and can be a powerful source of motivation to act in ways that affect others in a very public way, whether a merchant in Tunis sets himself on fire and ignites a revolution, or a 
troubled young man shoots indiscriminately in an elementary school. ${ }^{8}$ Honig, in the wake of Arendt, dismisses the call of suffering as an appropriate source for political action (2013, p. 209), preferring the language of solidarity to that of empathy. In a similar Arendtian vein, Ella Myers (2013) points to a way of distinguishing between solidarity and empathy by distinguishing between care for others (what brings us to empathize) and care for the world (what makes us come in solidarity around a cause rather than around each other). But these attempts at displacing empathy for someone's suffering from the proper domain of politics artificially sever politics from the suffering that sometimes animates it and motivates it: what is it that brings us to solidarize with someone or around something in the first place? For both Honig and Myers, the sources of solidarity do not seem to matter. For Honig, Antigone's suffering is a mere occasion to conspire against Creon. In Honig's quest to maintain Antigone as a sovereign, strong political actor, her vulnerability is quickly brushed aside. But it is precisely vulnerability, and its recognition in another, that sometimes ignites political action. The meeting of Richard Martinez, the father of one of the victims in the Santa Barbara shootings, with Peter Rodger, the father of the gunman, for the sake of gun control policies is a recent example of this. ${ }^{9}$

As suffering breaks identities and communities, and as these boundaries crumble, political possibilities open to constitute identities and public spaces alternative to, or in protest against traditional ones. Of course, the movement beyond the breaking, towards some form of solidarity and political action, is not a necessary element of the suffering itself. It needs to be wrestled away from cynicism and despair through exchange, expression and articulation. Nor is the claim of suffering irresistible: it needs to be heard, acknowledged and mediated as - for example - coming from someone whose suffering I wish to relieve. 'Levinasian' approaches underscoring the irresistibility of the call from the other oversimplify what I call the situation of suffering as immediately impinging on one's responsibility. But it is not clear, for example, that victims' families witnessing the execution of their loved ones' murderer fail to acknowledge their suffering. They do acknowledge it, and indeed may find solace in it. The 'call' then is mediated and not irresistible. Deeming the call immediate tends to reduce responsibility to a singular affair, or a dyadic relationship: it is one that is called. Butler's approach has been criticized for this (Shulman, 2011; Myers, 2013).

In between Honig's and Butler's position, I want to insert Jaspers's phenomenology of boundary situations as a way to account for suffering as a situation, contested and plural. Jaspers's philosophizing begins with situation: we cannot conceive the individuality that interests him in abstraction of the places, the time and the people that surround it and in some way constitute it. In this sense, any human experience already calls into question not only the individuals immediately experiencing it, but a broader web around them. Suffering itself is a situation, more than an experience exhausting itself within the body or the psyche of a single individual, without outside cause or reverberation. Situations such as suffering, death, guilt and struggle actually 
have a privileged role in making us aware of our finitude and entanglement with others, and thereby deepen our existential awareness. ${ }^{10}$

Jaspers uses the language of boundary in association with suffering first in his Psychologie der Weltanschauungen (1919). There he identifies suffering as the common element of boundary situations, situations where we find ourselves without reference points, and where everything is doubted (1919, pp. 202-203). Our certainties, our habits, the stable ground of our existence dissolve under our feet when we are confronted with them. The area along the boundary is a land of disorientation, but can also be a land of possibility and discovery, of re-orientation. At the same time as it opens us to pain and fright by way of the wound, suffering may force on us an awareness of limits, of vulnerability, and of our ability to respond to them. Jaspers's insight is that when we grasp suffering as inevitable and as a defining trait of the human condition, it does not just happen to someone, an 'other'. It is a situation that entangles those around it as more than mere witnesses, and thereby opens possibilities of existential and, I would add, political transformation. In a way, as we will see, he breaks down the difference between experiencing and witnessing suffering by characterizing suffering as something that hits the possibility of one's own being regardless of whether it is experienced or witnessed. The boundary and our response to it unmake the identity we knew and had consolidated in the past, and help to bring about a new one. They break through the shells that had protected and solidified who we are and make us porous to others (1919, pp. 269-288). ${ }^{11}$

When suffering opens the boundary of our skin and brings us to the boundary of our ability to master and control (the world around us, our autonomy, our feelings, our composure), we are left to face our powerlessness. Jaspers notes that openness to the raw wound is not a condition we can endure in depth for a considerable length of time. We need to cauterize and bandage it in order to go about living our life. We need to rationalize, find explanations, vindicate and endow our suffering with meaning drawn from this world or another. We need to know, or at least believe, that there will be a time when suffering will end, and we want to know how to get there. Jaspers notes that these are all ways in which we close the boundaries of the wound, but also the other boundaries (of our identity, of our existence) as possibilities that suffering opens (1919 and 1969). One way in which we close these openings is by putting ourselves at a distance from suffering, abstracting from it. This process of abstraction is a temptation not only for witnesses to suffering, but sometimes even to the sufferers themselves. So terrifying is suffering that we seek to domesticate it in any way we can. In the hurry to eliminate, escape or evade however - we may miss the opportunity to think and reflect, for example, on suffering as an ultimately inescapable dimension of the human condition and on shared vulnerabilities across bitter divides.

Here one can find some convergence with Butler (2006). It is not surprising that the current wave of emphasis on suffering and mortality would find (often unacknowledged) predecessors among the so-called 'existentialists'. But I want to 
suggest that turning to Jaspers moves us forward in this debate in two ways. First of all, he gives us insight into the path between the 'call' of suffering and political action, which is left implicit by both Levinas and his contemporary followers. He mediates the call by embedding it into a situation, which complicates it and possibly politicizes it. Secondly, he locates the boundary situation of suffering along other boundary situations, including - significantly for the purposes of this article - struggle.

In Philosophy vol. 2 Jaspers connects the unmaking of suffering to what suffering could make: action with others. Rather than displacing suffering as a politically suspicious phenomenon, as both Honig and Arendt seem to do, he investigates the privileged connection between what is destroyed and the space that destruction may open. Let us look at this path of 'existential elucidation' closely. Jaspers describes a 'desultory genesis of boundary situations' in stages and leaps, to point that passage from one stage to the next is not automatic (or 'irresistible'), but rather a precarious existential achievement $(1969$, p. 179). The natural scenario is in fact for him the evasion of suffering, through a hasty attempt to close the wound. One may move then to disembodied solipsism (first stage), to existential awareness (second stage), to concrete action among others (third stage). This path in a way tells a story of political involvement, and brings together what I have heretofore characterized as a tension between suffering as an idiosyncratic experience on one hand, and suffering as a political situation on the other.

I am always in a situation, Jaspers suggests, but I am not always aware of this. I may be denying, or be oblivious to, the ties that bind me to certain people, certain times and certain places. The experiences associated with boundary situations (death, struggle, suffering, guilt), however, tear us from our distraction and help us become aware of our situation. This opportunity we may fight and resist: after all these are not pleasant experiences. One way in which one hides from them is by seeking to confront them abstractly, as a universal 'I'. Here, in the first stage, the stage of abstraction, I am 'the pure eye that meets no other eye and looks upon all things, but not into itself' (1969, p. 180, emphasis added).

At the same time as they push us to flee our body, however, boundary situations make inescapable for us the consideration of our bodily, situated humanity. In the second stage of actualization of the situation, 'having previously, unshakable in my knowledge, dismissed the boundary situations as alien to myself', I begin to see them 'as possibilities that hit the essence of my being'. At this stage I overcome my denial of and abstraction from them, and find myself in them whether they are affecting me directly, or happening to someone else: I do meet someone else's eyes. The world, no longer a mere object, now contains my 'shaken self', and I begin to fear for what the boundary situations (finitude, death, suffering, guilt and struggle) may jeopardize. In doing so, I embrace suffering as definitive and unavoidable.

The third stage is when actualization is accomplished. While in the second stage we remain at the level of contemplation, in the third we return to embodiment into a finite and concrete historical existence. I no longer know the boundary situation 
objectively, as existing for man at large, nor do I elucidate it as a possibility, but I realize it and am it: a 'unique translation, a realization in personal existence' (1969, p. 181). At the second stage it was the dimension of unlimited possibility that was opening up, but at that stage I was 'not yet what I know as I philosophize'. I did know boundary situations, but knew them abstractly, hence in a way that hardly befits them. In the third stage, these infinite possibilities are narrowed down to the few practical choices I make, and actions I take among others, and the specific responses/ courses of action I enact out of the infinite intellectual and existential possibilities that confront me. ${ }^{12}$

The uncovering of vulnerability in the first stages of Jaspers's process of elucidation is similar to the one Butler discusses as attending to mourning. In mourning, as in other boundary situations, we feel dispossessed of the solidity of our previous identity: we embark on a transformation, 'the full result of which we cannot know in advance' (Butler, 2006, p. 21). We lose the control we had over ourselves, and Butler (more explicitly than Jaspers) delineates the political implications of this transformation:

Many people think that grief is privatizing, that it returns us to a solitary situation and is, in that sense, depoliticizing. But I think it furnishes a sense of political community of a complex order, and it does this first of all by bringing to the fore the relational ties that have implications for theorizing fundamental dependency and ethical responsibility. If my fate is not originally or finally separable from yours, then the 'we' is traversed by a relationality that we cannot easily argue against; or, rather, we can argue against it, but we would be denying something fundamental about the social conditions of our very formation. (2006, pp. 22-23)

But while Butler rightly focuses on a relationality that also sits at the core of Jaspers's notion of situation, she rushes to a 'we' and, via Levinas, to the irresistibility of the call. Unlike Butler, for Jaspers the call is never quite irresistible. It depends crucially on existential awareness, which is occasioned by experiences of suffering, but is developed into a sense of responsibility only desultorily and precariously when those experiences are situated and appreciated as inevitable and defining of us as humans. Jaspers's contribution is in gesturing to the fact that the opportunity for openness hinges on how we live through the wound, as individuals and - I would add - as a society: whether we hastily choose to close it and deny it, or whether we have it be an occasion for existential elucidation. He gives us insight into the emergence of that complex order of political community that Butler mentions in the passage above.

Moreover, and this is what makes Jaspers such an intriguing interlocutor between Butler and Honig, suffering is not for him the only boundary situation. Among the other, equally defining and inescapable realities of human existence, is also the boundary situation of struggle. Groups, social orders, states and individuals struggle over the material conditions of their own existence. They also struggle over 'rank and 
echo'. This latter kind of struggle is productive rather than destructive: an agon (Jaspers's word) for creativity 'in which each antagonist will give the other what he himself has won' (1969, p. 205). While I cannot dwell on Jaspers's compelling analysis of struggle, what I want to emphasize is that the path of existential awareness, which I have characterized as a path to political involvement, does not for him end with a pacification built on the grievability of all human life: any such pacification would be again an evasion of the boundary situation:

no definitively peaceful state of human community life is either empirically existent or construable as a possibility ... if I want to live, I must be a beneficiary of violence and at some time its victim; I must extend help and gratefully accept help; I must limit the clear either-or and twist it into agreements and compromises. In this boundary situation there is no objective solution for all time; there are only historic solutions for the time being. (Jaspers, 1969, p. 211)

The path of existential awareness, then, does not end at all, but rather remains at the mercy of the willingness of human beings to communicate and see themselves as entangled with one another.

I am reading Jaspers's third stage of existential elucidation as the one involving (political) action, encouraged by his characterization of this stage as the one when the elucidation translates into decisions and a realization in concrete existence, but Jaspers is rather coy on this point. He may have believed that extensive treatment of this stage would have meant engaging in specific prescriptions for action, which he did not think was the philosopher's job (and would have been self-defeating since each path of elucidation must be original and autonomous), but the fact remains that here lies undeveloped the most promising entry point into the political implications of Jaspers' thought. At stake is how the traumatic experiences underlying boundary situations may open the door to political action, and how it is that they come to matter to us when they happen to someone else. This third stage is the quintessentially political stage, where we act. Even more importantly, here we act together with others.

What is it that prompts one to move from the stage of solitude to the stage where one imagines boundary situations as possibilities for oneself and concrete others, and then act among these others? How others come to play in the transition from one stage to another, as well as in the (re)constitution of one's identity, is not made explicit by Jaspers. This account perhaps cannot be general, but must rather be concrete and particular: we cannot know unless we delve into those specific situations, and explore how they encompass different actors and what the relationships among those actors are. Here is where a turn to literature is useful: Camus's The Plague offers a phenomenological account of how reorientation towards others may arise in a boundary situation. In the next section, I read the journey of three of The Plague's characters as following closely Jaspers's path of existential elucidation from the evasion of the trauma of suffering to what I read as the creation of a new 
public, in alternative to failed public efforts to contain the plague. The journeys intersect in meaningful ways, each character challenged in his perspective on the situation of suffering by the others, and in the process reconstituting his own identity and constituting a new public enterprise. While the plague as a situation of suffering is one, within it struggle and contend multiple perspectives. This is not an instance in which a focus on suffering and finitude allows us to bypass the intractable divisions of politics (Honig, 2013, p. 17). Rather, we here see the characters traversing those divisions: not immediately springing into action, but prodding and questioning each other to find ground common enough for political action.

\section{A Tale of One City, and Four Characters}

It is not a choice for the dwellers in Oran to be isolated from the rest of the world, and to be bound in destiny to people they may not know nor care about. Yet, within this constraint, they have a say about the stake they will take in the situation. The backdrop to their journey is the city of Oran, a city slow in letting the new events shake its torpor. It refuses for a long time to compose the disturbing signals into the shape of a threat to be taken seriously. It ignores, minimizes and sanitizes the suspicions of its most alert citizens in order to maintain routines it cherishes in their dullness. ${ }^{13}$

The collapse of the citizens' private dreams when the plague reveals itself fully does not immediately drive them to political action, to the contrary. Two of the characters I discuss start their journey by resisting a definition of themselves within the situation of suffering in the city: Raymond Rambert, a journalist in Oran only for a short visit, and Father Paneloux, a Jesuit priest.

\section{Rambert}

When the authorities decide to isolate the city of Oran from the outside world to avoid contagion outside the walls, the most profound sense of isolation, entrapment and desire to escape is felt by those who do not belong in Oran in the first place. For some of them, the desire to evade the diseased city becomes an obsession. Raymond Rambert, a French journalist visiting Oran on a short assignment, finds himself separated from the life he knew and from his lover. In the face of suffering he first denies the situation, telling himself the quarantine has to be temporary, and then desperately and persistently tries to escape it (2004, p. 75). He insists to the Prefect of the town that 'he didn't have any ties to Oran, he wasn't going to remain there, he was there by chance and letting him go was the right thing to do'. He protests: 'I don't belong here' (2004, p. 76). Rambert tries to define himself out of the situation, as many tend to do when faced with suffering, their own or (especially) someone else's. In the face of the somber reminder by Dr Rieux that 'it's an absurd 
situation, but we're all involved in it, and we've got to accept it as it is', Rambert stubbornly repeats: 'But I don't belong here' (2004, p. 77). For a protracted portion of the novel, we see Rambert choosing isolation and becoming the embodiment of the infinite ways in which we can successfully ignore suffering as we focus on our own goals beyond and outside it.

Rambert becomes, however, increasingly ill at ease with his isolation. In the course of his contacts with Dr Rieux and Tarrou as he is plotting his escape he becomes apologetic about his desire to leave. He blames it on his longing for his lover in France (2004, p. 135). When the request for help by Tarrou becomes explicitly directed to him, he still seeks refuge in his private reasoning. But the boundary he set between himself and both the plague and efforts to fight it crumbles when he discovers that Dr Rieux, whom he had accused of being deaf to the plea of his love, was also separated from his wife by the city's walls. Learning of Dr Rieux's similar personal agony has for Rambert the powerful effect of forcing him to see the identity of their destinies. ${ }^{14}$

Following his momentous exchange with Rieux, Rambert relinquishes his condition as an outsider and begins to commit to action against the plague:

Until now I always felt a stranger in this town, and that I'd no concern with you people. But now that I have seen what I have seen, I know that I belong here whether I want it or not. This business is everybody's business. (2004, p. 184)

Rambert comes to see himself as encompassed by the same situation as the others and becomes ready to act in concert with them. Once he does, he allows himself to 'see the things he has seen', including the horrifying scene of the death Judge Othon's young child, which I have quoted at the beginning of the article. The spatial proximity of suffering is not what is decisive. What seems to be decisive in Rambert's case is apprehending - within the general, and for him rather abstract, situation of suffering- the particular suffering of Dr Rieux, a suffering that was closer to him and to which he was prepared to relate. Rambert begins with this private yet shared experience his commitment to the teams trying to contain the plague and assist the population of the city in coping with it.

\section{Paneloux}

The second character I consider is Father Paneloux, a Jesuit priest in Oran. Paneloux embodies the quick closing of the boundary that suffering opens, by recourse to religious faith. He also initially defines himself outside the situation of suffering, although in a different way from Rambert. He addresses the full cathedral, early in the novel, lashing out at the population of the city for its mistaken ways, and proclaiming the plague a fitting punishment for them. Paneloux's attitude towards the suffering of the people is distant: in his sermon he refers to the population and its 
sins, and offers a simple religious explanation for the plague: it is God's punishment for the evildoers. The situation is foreign to him; he sets himself apart from it and assigns himself the role of the critical outsider, his voice 'vibrant with accusation' (2004, p. 87). He contemplates the suffering intellectually, so to speak, as someone might in Jaspers's first or second stages. Indeed Dr Rieux calls him 'a scholar. He has not seen enough people die and that is why he speaks in the name of eternal truths' (2004, p. 97).

Paneloux later joins the effort to contain the plague, presumably out of a sense of religious duty. As his involvement in the common effort increases, however, we begin to see that the distance he had put between himself and the suffering diminishes, by virtue of his concrete engagement with suffering people ('seeing enough people die') rather than suffering as a general concept, filtered and explained by religious faith. Paneloux begins to define himself within the situation. This move occurs because of interaction with others, by way of Paneloux working with them and seeing himself as part of the struggling community, and culminates - once again - with the witnessing of Othon's child's slow and painful death. Father Paneloux, who had until a few minutes before retained some distance, is brought to his knees and to the invocation to God to save the boy. Later, during Father Paneloux's exchange with Dr Rieux, all the priest's beliefs and protective shells are attacked ('He was innocent, and you know it', the doctor exclaims in exasperation). These attacks, and the profound existential changes they bring about in Paneloux, are then translated in the priest's second sermon. In it, his tone is 'more mellow and more reflective', the words were at times pronounced with more hesitation and, importantly, he moves from an accusatory you towards the people to a compassionate we. Some of the beliefs he had articulated in the first sermon are still his, but he now admits that he had pronounced them without any charity. In the second sermon Paneloux places himself within the situation and in fact may be seen as reaching that third stage of actualization of the situation that Jaspers discusses in Philosophy vol. 2.

The path to both existential elucidation and political action hinges for both characters on the willingness to see themselves as situated, and as situated with others in an inescapable situation of suffering. Work and interaction with others help them draw suffering from generality to a concrete situation of which they regard themselves as a part.

\section{Tarrou (and Rieux)}

Both Rambert and Paneloux were able to join, when they were ready, an existing public effort against the plague. Let me now briefly turn to the initiator of that effort. Tarrou is a character presented by the narrator as somewhat extravagant, but genuine. He is a well-to-do visitor to Oran who, rather than consuming himself with thoughts of escape like Rambert, takes an active role in the situation. While accepting that his 
situation defines him, and that escape is impossible, he sets out to define it in turn. First of all, he defines it literally, by narrating it: his notebooks (we find out at the end of the novel) are among the original sources on which the narrator of the story relies for his own account. ${ }^{15}$ Second, he defines it by his decision to constitute, and his effort to build, an alternative public response to the plague based on grassroots ingenuity. When he approaches Dr Rieux with his plan, Tarrou comes to him as an utterly powerless figure, according to traditional definitions and measures of power. He is not qualified to deal with the plague from a professional point of view (he is not a doctor or public health expert - in fact, his professional qualifications are unclear), and he is a visitor, not a citizen of Oran. He is the most unlikely of public figures, planning to create public action in the most difficult of circumstances: on the verge of catastrophe ('In a fortnight or a month at most', he tells the doctor, 'you'll serve no purpose here. Things will have got out of hand' - 2004, p. 111). His plan is simple and somewhat naïve when read against the circumstances:

I've drawn up a plan for voluntary groups of helpers. Get me empowered to try out my plan, and then let's sidetrack officialdom. In any case the authorities have their hands more than full already. I have friends in many walks of life; they'll form a nucleus to start from. And, of course, I'll take part in it myself. (2004, p. 112)

When asked by the doctor what prompted his initiative in the face of the dangers involved, a crucial exchange begins, an agonistic engagement in which the reasons sustaining the public action to come are refined in dialogue. Tarrou apparently evades Dr Rieux's fundamental question ('Have you weighed the dangers?') by repeatedly questioning the doctor on the same issue. In fact, he is not evading the question, but laying the foundations to build an answer in concert: 'My question's this - said Tarrou - Why do you yourself show such devotion, considering you don't believe in God? I suspect your answer may help me to mine'. ${ }^{16}$

The two characters probe each other's attitudes towards the plague and reasons to act against it. The suffering the plague flushes on the city of Oran is looked at squarely and turned into existential mobility and political mobilization. This rebellion, the grounding of Tarrou's public initiative against suffering, is not rooted in the ambition to eradicate suffering once and for all from the human condition, but rather precisely in the acceptance of it as a situation, ineluctable in general yet unacceptable in the particular. ${ }^{17}$

Camus shows in the journey of the characters I have analyzed, with what we might call literally a characterization of the boundary situation of suffering, how this process, initially intimate or dialogical at most, becomes political. It becomes political both in the sense that it brings about action in concert, and in the sense that it highlights how the new public being constituted is far from mindlessly united in the face of an irresistible call. Rather, it is constituted by different actors, responding to different motivations, divided among and within themselves, nonetheless working 
together in pursuit of a common goal. Not only does Camus give this process a political dimension, but he gives it a somewhat revolutionary dimension. Tarrou is not a political character in any traditional sense of the word, and yet he manages to overtake 'officialdom' and build a public space for action in alternative to other traditional (and ineffective, in 'catastrophic' times) public spaces.

Suffering and a politics of counter-sovereignty are inextricable in my analysis of the political initiative spearheaded by Tarrou in The Plague. I have highlighted how the suffering in this instance was necessary to bring these particular actors to constitute their public effort, and I have offered my analysis as alternative to Honig's in Antigone, Interrupted, where suffering seems to be deployed more as instrument in existing political battles between democracy and aristocracy, than as a politically transformative force (Honig, 2013, p. 97).

\section{Political Action and the Displacement of Suffering}

While I am sympathetic to Honig's and Arendt's celebration of action and power, and their constitutive contribution to democratic theory and healthy democracies, I fear that such celebration displaces suffering as an equally constitutive element of politics and in particular, as I have tried to show, democratic and radical politics. Suffering appears in both theorists as some sort of unaccounted for 'remainder' (see Honig, 1993). That we should resist the temptation to secure new political ways on an understanding suffering as an unproblematically universal summum malum is a timely and wise warning, ${ }^{18}$ but the warning need not be wed to a reading of suffering as necessarily passive and apolitical. In this article I have tried to negotiate the complexities entailed in suffering as both an inherent trait of the human condition, and an idiosyncratic experience that defies interpretation. In this tension, many political possibilities disclose themselves. By presenting suffering as situation, rather than foundation, I present it as ground for contestation and elucidation, while emphasizing its potential for unmaking. Underlying my approach has been the insight that suffering does not come to be shared in an unmediated way as a matter of necessity, physical reaction or unanimous interpretation, but rather as a concerted response to crises that present an urgency that is peculiar, and whose peculiarity must be recognized.

I have characterized this peculiarity in terms of unmaking, of the solidities of Jaspers's unreflective existence, of the routines of Oran's citizens and its visitors, of the shells protecting The Plague's characters. But I have also attempted to emphasize the doors to political opportunity that this unmaking opens. In Antigone, Interrupted Honig distinguished, within the conceptual universe of grieving, between languishing and lamentation on one hand, and rage on the other. With Jaspers and Camus, I have shown rage, rebellion and, indeed, action, to be intimately connected with suffering itself. 
I have not claimed that suffering is constitutive of all political action, but rather that debates around the meaning and the best way to contain our suffering and the suffering of fellow human beings are at the core of contemporary politics, and they constitute often an impetus to engage in political enterprises. One can think, for example, of the momentum gained by the constitutive process of the International Criminal Court in the wake of the genocides in Bosnia and Rwanda. We are not, especially as modern subjects and the citizens of contemporary liberal democracies, already political subjects as Arendt would want us. Yet, the liberal assumption that our private, individual existence is prior to our being situated is itself, phenomenologically, a fiction. We need, therefore, to think through what it is that brings us together to act in concert. ${ }^{19}$ In our situation, it appears that shocks to our modern routines and regularities have a strong role in this. And perhaps none of them is more powerful than suffering.

My analysis of Camus and Jaspers discloses that a consideration for others as embroiled in the same 'existential realities' as White calls them, or 'boundary situations' as Jaspers called them, is one important element for turning experiences of suffering into acts of political rebellion, or at least action. The realization that I am situated with others is a fundamental step towards achieving the boundary for Jaspers, and we have seen the role that seeing themselves as situated with others has played in the evolution of The Plague's characters. Conversely, Jaspers regards cynicism and resignation as closing the boundary, and in The Plague we see the character of Cottard as an example of suffering that closes in on itself and resists others. Cottard is profoundly alone throughout the novel: suicidal at the beginning and murderous at the end. His only real companion is the suffering itself, which the plague brings upon the city.

Heinrich Blücher discusses Camus and Jaspers together as rebellious humanists who tried to re-establish certain values of humanism 'so that we have a leg to stand on in the nihilistic situation' (Blücher, 1952). ${ }^{20}$ I have suggested that for both authors others, understood as sharing situations, are constitutive of this leg, an anchor to a minimalist humanism in a nihilist tide. Their writings point to politically significant exceptions to the bleak diagnosis offered by nihilism for the human condition in the twentieth century, a diagnosis they otherwise shared.

\section{Acknowledgements}

I would like to thank Mary Dietz, Bill Scheuerman, Eric Weitz, Amit Ron, Michael Illuzzi, Alisa Kessel, Daniela Mansbach, Jonathan Havercroft, Matt Weidenfeld, Ayça Çubukçu and Simona Forti for valuable comments. The editor and anonymous reviewers of Contemporary Political Theory have helped in making this a much better article. I also gratefully acknowledge the scholarly and financial support I received at the European University Institute while I was a Max Weber Fellow there. 


\section{About the Author}

Giunia Gatta is broadly interested in how experiences traditionally regarded outside the boundaries of politics, such as suffering and guilt, become sources of political mobilization. She draws on Continental political theory, international political theory, and the theory of liberalism. At present she is working on two book manuscripts: one on the liberalism of Judith Shklar, and the other on Karl Jaspers's political theory of boundary situations. Her article "Visiting or House Swapping? Arendt and Jaspers on Empathy, Enlarged Mentality, and the Space Between" has just published in Philosophy and Social Criticism.

\section{Notes}

1 I do not think that Honig would disagree with this. Her target in Antigone, Interrupted is not suffering in itself, but rather a universalistic reading of suffering. Yet, she also definitely inherits from Arendt a rather contemptuous stance towards suffering and its political signification. She would argue, I suspect, that the political work of signification and re-signification of suffering is neatly distinguishable from the experience of suffering itself. With this, I take issue.

2 Incidentally, drawing attention to this level challenges the view that the signification of suffering at the community or cultural level is monolithic and univocal.

3 Camus is here talking about a boy's losing battle against the plague. Of course, he wrote The Plague as a metaphor for the spread of Nazism in Europe in the 1930s. Like Camus, in this article I blur the distinction between suffering as the result of natural forces and suffering as a result of political forces because my focus is on the rebelling victims and their suffering. By doing this, I do not mean to trivialize the important question of the attribution of responsibility for the suffering of others, which deserves the copious attention it has been given by legal, political and ethical theorists.

4 Seeing should not be interpreted literally here. The ability to 'see' suffering in the sense intended here does not overlap perfectly with the material fact of being in its presence. One could very well be in the presence of suffering and still not feel part of the situation, as when abstraction blinds one's seeing of suffering. See, most persuasively, Scarry (1985). I will re-conceptualize this 'seeing' as defining oneself within a situation of suffering later in the article.

5 Honig dwells at length on the idiosyncrasy of suffering, and mourning in particular, in her argument for the vernacular, non-universal character of suffering. See, for example, her reading of a famous scene in Michael Moore's Fahrenheit 911, in which Lila Lipscomb is brought together in mourning with another woman, only to be soon driven apart from her by their drastically different ways of mourning the deaths in question (Honig, 2013, pp. 33-34).

6 I think the underdetermination of these constitutive experiences articulated in Sustaining Affirmation (2000) shelters White against Honig's interpretation of him as one of those trying to emphasize the universality of suffering. He seems to somewhat forfeit this possible defense in his later Ethos of a Late Modern Citizen (2009).

7 Insofar as the child indeed rebels, perhaps the words Camus writes in The Rebel can be seen as applying to him: 'the affirmation implicit in each act of revolt is extended to something which transcends the individual in so far as it removes him from his supposed solitude and supplies him with reason to act' (Camus, 2000, p. 21).

8 Even in these two examples we see that suffering rarely, if ever, happens in a void. Here, important elements of the 'situations' are the economic crisis in Tunisia on one hand, and on the other lack of 
adequate mental health care and gun control laws, bullying, and a tendency to dispose of awkward children in American society.

9 'I've been told that the shooter's father has said he wanted to devote his life to making sure that doesn't happen again. I share that with him', Martinez said. 'He's a father. I'm a father. He loved his son. I love my son. His son died. My son died' (Peralta, 2014).

10 Borrowing language that Samuel Chambers and Terrell Carver use in their reading of Butler, we could say that for Jaspers ethical considerations flow from ontological ones. See Chambers and Carver (2008, pp. 92-117).

11 Simona Forti's reading of Levinas on the question of evil brings to the fore interesting points of convergence with Jaspers on boundary situations. Her general task in her book is also to break down a reading of evil based on a binary of victim and perpetrator. See Forti (2014).

12 I think this stage bears intriguing similarities to Arendt's notion of natality.

13 Camus (2004, p. 6). We can identify this as Jaspers's unreflective stage of denial at the outset of the path to existential elucidation.

14 When he discusses how rebellion 'does not occur only amongst the oppressed but that it can also break out at the mere spectacle of oppression of which someone else is the victim', Camus distinguishes identity of destiny from mere psychological identification, 'a mere subterfuge by which the individual contrives to feel that it is he who has been oppressed' $(2000$, p. 22). It seems to me that by drawing this distinction he intends to isolate psychological identification as an a-political matter of emotion, from what Jaspers would call a (political) matter of situation.

15 Also at the end of the novel we find that Dr Rieux is the narrator of the story. He is also, therefore, someone who takes action in defining the situation of suffering not only by taking a political initiative against it, but also by way of language.

16 Camus (2004, p. 114). Tarrou declares, after the exchange, that Dr Rieux 'is right'. Rieux asks Tarrou what he knows about it and Tarrou replies that he has 'little left to learn' and that yes, he imagines he knows 'everything about life'. This could very well mean that what he knows is that everything can be known by way of exchange with others, that truth is necessarily communicative. It is significant that just after pronouncing these words Tarrou slips on a step in the dark stairs outside Rieux's office and he steadies himself 'by gripping the doctor's shoulder'.

17 Jaspers had something similar to rebellion in mind when he wrote:

'If I act as if suffering were avoidable rather than definitive, I am not yet in the boundary situation ... I fight suffering on the premise that it can be abolished. I actually have some success in this fight, which comes to be a condition of human existence. Everyone takes part in it; everyone, as long as he is honest and perceives the situation, will ask himself to wage this battle with the utmost effort, by all rational and empirically promising means. Success, of course, will always be limited ... I live in the tension of wanting to say Yes and never being capable of a definitive Yes' (1969, pp. 202-203).

18 I do not think theorists like White and Butler quite yield to this temptation, but this is an argument that exceeds the bounds of this article.

19 For an insightful defense of the relevance of motivation in political theory, see Critchley (2007).

20 On Camus's ambiguous relationship with humanism, see Isaac (1992, pp. 68-104).

\section{References}

Arendt, H. (1963) On Revolution. New York: Penguin.

Blücher, H. (1952) Why and how we study philosophy, unpublished lecture series, Lecture I, Bard College,

Blücher Archives. http://www.bard.edu/bluecher/lectures/why_study/why_study_pf1.htm, accessed 1 October 2012.

Butler, J. (2006) Precarious Life: The Powers of Mourning and Violence. London: Verso. 
Camus, A. (2000) The Rebel. New York: Penguin.

Camus, A. (2004) The Plague, the Fall, Exile and the Kingdom, and Selected Essays. New York: Alfred A. Knopf.

Chambers, S. and Carver, T. (2008) Judith Butler and Political Theory. New York: Routledge.

Critchley, S. (2007) Infinitely Demanding. London: Verso.

Forti, S. (2014) New Demons. Stanford, CA: Stanford University Press.

Gatta, G. (forthcoming) Visiting or house swapping? Arendt and Jaspers on empathy, enlarged mentality, and the space between. Philosophy and Social Criticism, first published on 7 September 2014, doi:10.1177/0191453714548501.

Honig, B. (1993) Political Theory and the Displacement of Politics. Ithaca, NY: Cornell University Press.

Honig, B. (2013) Antigone, Interrupted. Cambridge, UK: Cambridge University Press.

Hutchison, E. (2010) Trauma and the politics of emotions: Constituting identity, security and community after the Bali Bombing. International Relations 24(1): 65-86.

Isaac, J. C. (1992) Arendt, Camus, and Modern Rebellion. New Haven, CT: Yale University Press.

Jaspers, K. (1919) Psychologie der Weltanschauungen. Berlin: Springer Verlag. http://archive.org/stream/ psychologiederwe00jasp\#page/n3/mode/2up, accessed 29 September 2012.

Jaspers, K. (1969) Philosophy, Vol. 2. Chicago, IL: University of Chicago Press.

Myers, E. (2013) Worldly Ethics. Durham, NC: Duke University Press.

Peralta, E. (2014) Father of Santa Barbara Killer Meets Victim's Dad. NPR report, 16 June. http://www. npr.org/blogs/thetwo-way/2014/06/16/322592320/photos-father-of-santa-barbara-killer-meets-victimsdad?utm_source=facebook.com\&utm_medium=social\&utm_campaign=npr\&utm_term=nprnews \&utm_content=20140616, accessed 17 June 2014.

Rorty, R. (1989) Contingency, Irony, and Solidarity. New York, NY: Cambridge University Press.

Scarry, E. (1985) The Body in Pain: The Making and Unmaking of the World. New York: Oxford University Press.

Shklar, J. N. (1982) Putting cruelty first. Daedalus 111(3): 17-27.

Shklar, J. N. (1984) Ordinary Vices. Cambridge, MA: Harvard University Press.

Shklar, J. N. (1989) The liberalism of fear. In: N. Rosenblum (ed.) Liberalism and the Moral Life. Cambridge, MA: Harvard University Press, pp. 21-38.

Shulman, G. (2011) Acknowledgment and disavowal as an idiom for theorizing politics. Theory \& Event 14(1), doi:10.1353/tae.2011.0003 .

White, S. (2000) Sustaining Affirmation. The Strength of Weak Ontology in Political Theory. Princeton, NJ: Princeton University Press.

White, S. (2009) The Ethos of a Late Modern Citizen. Cambridge, MA: Harvard University Press. 